\title{
PENGARUH LIFE STYLE, KUALITAS PRODUK DAN STORE IMAGE TERHADAP KEPUTUSAN PEMBELIAN
}

\author{
Astri Ayu Purwati ${ }^{1}$, Yusrizal $^{2}$, Indah Cipta Ramadhani ${ }^{3}$ \\ Sekolah Tinggi Ilmu Ekonomi Pelita Indonesia ${ }^{1,2,3}$ \\ Email. astri.ayu@lecturer.pelitaindonesia.ac.id ${ }^{1}$
}

\begin{abstract}
ABSTRAK
Tujuan penelitian ini yaitu untuk mengetahui dan menganalisis pengaruh life style, kualitas produk, dan store image terhadap keputusan pembelian komsumen di Toko Mulia Internasional Fashion Plaza Sukaramai Pekanbaru. Metode yang digunakan adalah analisis regresi linier berganda.Sampel yang digunakan sebanyak 100 responden.Hasil penelitian ini menunjukkan bahwa life style dan kualitas produk berpengaruh signifikan terhadap keputusan pembelian, sedangkan storeimagetidak berpengaruh signifikan terhadap keputusan pembelian konsumen di Toko Mulia Inernasional Fashion Plaza Sukaramai Pekanbaru.
\end{abstract}

Kata Kunci: Life Style, Kualitas Produk, Store Image, Keputusan Pembelian.

\section{ABSTRACT}

The purpose of this research is to find out and analyze the influence of life style, product quality, and store image on consumer purchasing decisions atMulia InternationalStore Fashion Sukaramai PlazaPekanbaru.The method used is multiple linear regression analysis.The sample used was 100 respondents.The results of this study indicate that life style and product quality have a significant effect on purchasing decisions, while store image has no significant effect on consumer purchasing decisions inMulia InternationalStore Fashion Sukaramai PlazaPekanbaru.

Keywords: Life Style, Product Quality, Store Image, Purchasing Decision.

\section{PENDAHULUAN}

Semakin tingginya tingkat persaingan di dunia bisnis dan kondisi ketidakpastian memaksa perusahaan untuk mencapai keunggulan bersaing agar mampu memenangkan persaingan.Salah satunya dengan cara membuat sesuatu yang berbeda untuk konsumen. Pengusaha harus menciptakan strategi yang tepat agar dapat memasarkan produknya. Saat ini perusahaan harus mampu memuaskan kebutuhan dan keinginan konsumen untuk mendapatkan keuntungan.Mempelajari serta memahami apa saja kebutuhan konsumen itu, memahami secara keseluruhan untuk dapat maju serta berkembang. Memahami dengan cara bahwa konsumen itu adalah pasar sasaran produk, jika produk tersebut masih belum dianggap mampu memenuhi kebutuhan serta keinginan konsumen akan lebih untuk tidak membeli produk tersebut, namun apabila produk itu sesuai 
dengan keinginan ataupun kebutuhan konsumen akan membelinya.Persaingan yang ketat antar perusahaan menimbulkan kegiatan perusahaan yang bergerak dibidang yang sama,seperti retail.Saat ini perkembangan bidang retail yang cukup pesat salah satunya bergerak di bidang fashion.

Toko Mulia Internasional Fashion merupakan salah satu gerai retail yang ramai pengunjungnya. Bisnis ini bergerak dibidang pakaian jadi pria yang berkembang pesat yang memberikan kualitas yang baik. Toko Mulia didirikan sejak tahun 2007. Toko Mulia Internasiona Fashion menjual pakaian pria seperti kaos, kemeja, baju koko, celana jeans dan perlengkapan pria lain nya. Toko Mulia awalnya hanya memiliki satu ruko, tetapi karena banyak peminatnya toko ini berhasil mengembangkan nya menjadi 3 ruko bahkan membuka beberapa cabang. Sejauh ini Toko Mulia Internasional sudah memiliki beberapa cabang di Komplek Plaza Sukaramai yang bergerak dibidang yang sama tetapi menjual produk yang berbeda seperti menjual baju anak-anak, baju remaja, baju untuk ibu-ibu, menjual jilbab dan baju olahraga.Toko Mulia dapat berkembang dan memiliki banyak cabang tentu bukan sesuatu hal yang mudah untuk dicapai dan diminati banyak konsumen. Menjaga dan memberikan kualitas produk yang baik merupakan salah satu cara agar konsumen melakukan pembelian pada produknya. Dalam beberapa tahun gerai retail ini mengalami perkembangan yang pesat, hal ini dapat dilihat pada tabel dibawah ini.

Tabel 1

Data Penjualan Toko Mulia Internasional Fashion tahun 2013 - 2017

\begin{tabular}{cccccc}
\hline Bulan & 2013 & 2014 & 2015 & 2016 & 2017 \\
\hline Januari & 370.675 & 294.665 & 340.083 & 386.675 & 391.564 \\
\hline Februari & 375.510 & 324.682 & 321.451 & 325.820 & 365.912 \\
\hline Maret & 400.640 & 316.015 & 324.082 & 305.550 & 410.015 \\
\hline April & 413.200 & 330.358 & 334.529 & 315.500 & 385.608 \\
\hline Mei & 441.125 & 360.095 & 371.829 & 451.125 & 1.160 .195 \\
\hline Juni & 520.615 & 810.950 & 1.120 .018 & 975.685 & 818.950 \\
\hline Juli & 790.500 & 845.741 & 759.436 & 960.210 & 564.751 \\
\hline Agustus & 798.755 & 552.706 & 429.492 & 661.636 & 377.706 \\
\hline September & 464.090 & 304.054 & 333.143 & 352.050 & 304.211 \\
\hline Oktober & 300.535 & 348.722 & 395.604 & 322.631 & 281.437 \\
\hline November & 353.060 & 376.814 & 307.749 & 321.800 & 276.814 \\
\hline Desember & 359.105 & 330.582 & 422.681 & 419.220 & 498.563 \\
\hline Total & 5.587 .081 & 5.195 .384 & 4.340 .079 & 5.797 .902 & 4.675 .531
\end{tabular}


Dari tabel 1 dapat diketahui bahwa data penjualan dari usaha Toko Mulia terjadi fluktuasi di setiap tahun 2013 hingga tahun 2017. Permasalahan yang menyebabkan terjadinya hal ini karena adanya situasi dimana terjadi pelonjakan pembelian yang cukup besar pada bulan-bulan tertentu. Misalnya pada tahun 2013data penjualan sebesar 5.587.081.000, dan pada tahun selanjutnya dapat dilihat pada tahun 2014 mengalami penurunan sebesar 5.195.384.000, dan pada tahun 2015 mengalami penurunan sebesar 4.340.079.000, sedangkan pada tahun 2016 mengalami kenaikan yang cukup besar yaitu 5.797.902.000, dan pada tahun 2017 mengalami penurunan sebesar 4.675.531.000 dapat dijelaskan bahwa data penjualan paling tinggi pada tahun 2016, sehingga dapat di jelaskan ada kenaikan dan penurunan pada 5 tahun terakhir data tersebut berfluktuasi.Di era globalisasi saat ini, fashion bukanlah sesuatu yang biasa lagi bagi masyarakat. Fashion menjadi bagian yang tidak dapat dilepaskan dari gaya keseharian, seseorang dapat menunjukan siapa dirinya dengan gaya.Selain itu, produk-produk yang dipasarkan harus memiliki kualitas dan tidak hanya sekedar produk biasa.

Berdasarkan pada uraian dan fenomena tersebut diatas, menunjukkan terdapat suatu masalah yang timbul dalam keputusan pembelian konsumen di Toko Mulia Internasional Fashionsehingga menjadi sesuatu hal yang menarik untuk dilakukan penelitian dengan mengambil judul "Pengaruh Life Style, Kualitas Produk, dan Store Image Terhadap Keputusan Pembelian Konsumen di Toko Mulia Internasional Fashion Plaza Sukaramai Pekanbaru".

Menurut penelitian Citra (2016) kualitas produk berpengaruh signifikan terhadap keputusan pembelian. Menurut penelitian yang dilakukan oleh Pratama (2015)gaya hidup, dan kualitas produk secara parsial berpengaruh signifikan terhadap keputusan pembelian. Menurut penelitian Lestari (2017) menunjukkan bahwa gaya hidup berpengaruh terhadap keputusan pembelian. Sedangkan menurut penelitian yang dilakukan Maretha \& Kuncoro (2011) store image memiliki pengaruh yang signifikan terhadap keputusan pembelian konsumen. Dan menurut penelitian yang dilakukan oleh Gunawan (2010) store image berpengaruh positif dan signifikan terhadap keputusan pembelian secara simultan dan parsial.

Adapun tujuan dalam penelitian ini adalah sebagai berikut : (1) Untuk mengetahui dan menganalisis pengaruh Life Style terhadap Keputusan Pembelian Konsumen di Toko Mulia Internasional Fashion Pekanbaru. (2) Untuk mengetahui dan 
menganalisis pengaruh Kualitas Produk terhadap Keputusan Pembelian Konsumen di Toko Mulia Internasional Fashion Pekanbaru. (3) Untuk mengetahui dan menganalisis pengaruhStore Image terhadap Keputusan Pembelian Konsumen di Toko Mulia Internasional Fashion Pekanbaru.

\section{KAJIAN TEORI}

\section{Pemasaran}

Pemasaran adalah salah satu kegiatan yang sangat penting dalam dunia usaha.Menurut Kotler \& Armstrong (2014)Pemasaran adalah proses dimana perusahaan menciptakan nilai bagi pelanggan dan membangun hubungan yang kuat dengan pelanggan, dengan tujuan menangkap nilai dari pelanggan sebagai imbalannya. Sedangkan menurut Ali (2011) Pemasaran adalah proses mengidentifikasi, menciptakan dan mengkomunikasikan nilai, serta memelihara hubungan yang memuaskan pelanggan untuk memaksimalkan keuntungan perusahaan.

Beberapa definisi pemasaran para ahli di atas, maka dapat disimpulkan bahwa pemasaran adalah suatu proses sosial atau fungsi organisasi dalam kegiatan bisnis yang bertujuan untuk menyalurkan atan mendistribusikan barang-barang dalam rangka memuaskan kebutuhan konsumen.

\section{Manajemen Pemasaran}

Dalam suatu perusahaan, manajemen pemasaran mempunyai peran penting untuk mencapai tujuan perusahaan. Tugas manajemen pemasaran adalah melakukan perencanaan mengenai bagaimana mencari peluang pasar untuk melakukan pertukaran barang dan jasa dengan konsumen. Keller (2016) mendefinisikan pengertian manajemen pemasaran adalah penganalisaan, pelaksanaan, dan pengawasan, program-program yang ditujukan utuk mengadakan pertukaran dengan pasar yang dituju dengan maksud untuk mencapai tujuan organisasi.

Assauri (2009) mendefinisikan manajemen pemasaran adalah kegiatan manusia yang diarahkan untuk memenuhi dan memuaskan kebutuhan dan keinginan melalui proses pertukaran.Berdasarkan definisi di atas maka dapat disimpulkan bahwa manajemen pemasaran adalah seni atau ilmu untuk memilih, mendapatkan, dan mempertahankan pasar sasaran dengan analisis, perencanaan, penerapan, dan 
pengendalian program untuk membangun dan mempertahankan pasar sasaran dengan maksud untuk mencapai tujuan organisasi.

\section{Life Style}

Michael R Solomon (2011) mengatakan bahwa gaya hidup mencakup aktivitas, minat dan opini. Menurut Satya Gunawan Yahya (2012) gaya hidup akan mempengaruhi keinginan seseorang untuk berperilaku dan akhirnya menentukan pilihan - pilihan konsumsi. Setiap orang memiliki gaya hidup yang berbeda, kemudian gaya hidup ini akan mempengaruhi budaya konsumsi dan juga barang-barang yang biasa mereka konsumsi, hal ini dapat dimanfaatkan oleh para pemasar untuk bisa meningkatkan efisiensi dan efektivitas pemasaran mereka.

\section{Indikator Life Style}

Menurut Philip Kotler \& Gery Amstrong (2008) gaya hidup atau life style adalah pola hidup seseorang yang tergambarkan pada psikografisnya. Psikografis membutuhkan pengukuran dimensi AIO utama konsumen yaitu : (1)Activities/ kegiatan ( pekerjaan, hobi, belanja, olahraga, kelas sosial ) (2) interest / minat ( makanan, mode, keluarga, rekreasi ). (3) Opinions ( tentang diri mereka sendiri, isu-isu sosial, bisnis, produk ).

\section{Kualitas Produk}

Menurut Lupiyoadi (2014) kualitas produk adalah sejauh mana produk memenuhi spesifikasi-spesifikasinya. Nilai yang diberikan pelanggan diukur berdasarkan kepercayaan (reliability), ketahanan (durability), dan kinerja (performance) terhadap bentuk fisik dan citra produk. Menurut Tjiptono (2008) kualitas produk merupakan perpaduan antara sifat dan karakteristik yang menentukan sejauh mana keluaran dapat memenuhi prasyarat kebutuhan pelanggan atau menilai sampai seberapa jauh sifat dan karakteristik itu memenuhi kebutuhannya.

\section{Dimensi Kualitas Produk}

Kualitas suatu produk baik berupa barang atau jasa ditentukan melalui dimensidimensinya. Dimensi kualitas produk menurut Tjiptono (2008): (1) Performance ( 
kinerja ), berhubungan dengan karakteristik operasi dasar dari sebuah produk. (2) Durability (daya tahan), yang berarti berapa lama atau umur produk yang bersangkutan bertahan sebelum produk tersebut harus diganti. Semakin besar frekuensi pemakaian konsumen terhadap produk maka semakin besar pula daya produk. (3) Comformance to specifications ( kesesuaian dengan spesifikasi ), yaitu sejauh mana karakteristik operasi dasar dari sebuah produk memenuhi spesifikasi tertentu dari konsumen atau tidak ditemukannya cacat pada produk. (4) Features (fitur), yaitu karakteristik produk yang dirancang untuk menyempurnakan fungsi produk atau menambah ketertarikan konsumen terhadap produk. (5) Reliability (reliabilitas), adalah probabilitas bahwa produk akan bekerja dengan memuaskan atau tidak dalam periode waktu tertentu. Semakin kecil kemungkinan terjadinya kerusakan maka produk tersebut dapat diandalkan. (6) Aesthetics (estetika), berhubungan dengan bagaimana penampilan produk. (7) Perceived quality (kesan kualitas), sering dibilang merupakan hasil dari pengguna pengukuran yang dilakukan secara tidak langsung karena terdapat kemungkinan bahwa konsumen tidak mengerti atau kekurangan informasi atas produk yang bersangkutan. (8) Serviceability, meliputi kecepatan dan kemudahan untuk reparasi, serta kompetensi dan keramah tamahan staf layanan.Dapat disimpulkan bahwa suatu dimensi kualitas merupakan syarat agar suatu nilai dari produk memungkinkan untuk bisa memuaskan pelanggan sesuai harapan.

\section{Store Image}

Menurut Keller\&Kotler (2009) Store Image merupakan persepsi masyarakat terhadap perusahaan atau produknya. Maka membangun citra sangat penting karena citra dapat mempengaruhi persepsi pelanggan dan publik. Store image atau citra toko memiliki pengertian pandangan atau persepsi masyarakat terhadap nama atau produk toko tersebut atau bisa juga diartikan sebagai penentuan posisi toko secara efektif, baik dari segi nilai, kualitas, dan harga (Sopiah \& Syihabudhin, 2008).

Citra sebuah toko adalah kepribadian sebuah toko yang menggambarkan apa yang dilihat dan dirasakan oleh konsumen terhadap toko tertentu (Sopiah \& Syihabudhin, 2008). Menciptakan sebuah citra yang baik bagi konsumen berarti memuaskan konsumen, mengingat konsumen yang merasa puas diharapkan akan melakukan pembelian, pembelian ulang dan bahkan memberitahukan kepada konsumen 
yang lain, hal ini akan membuat perusahaan dapat menempatkan pesaingnya diurutan rendah atau sebaliknya.

\section{Indikator Store Image}

Store image dapat diukur melalui indikator yang dikembangkan Christian Hadi Wijaya (2013) dan Tommy Soebagyo \& Dr Hartono M.M (2014) sebagai berikut : (1) Nama toko memiliki reputasi di mata konsumen. (2) Layanan toko yang dirasakan konsumen. (3) Kelengkapan barang dalam toko. (4) Memiliki Physical Facilities yang baik.

\section{Keputusan Pembelian}

Keputusan pembelian menurut Kotler dan Armstrong dalam Mardiansyah (2016) adalah tahap dalam proses pengambilan keputusan pembeli dimana konsumen benar-benar membeli. Kemudian Kotler dan Armstrong dalam Pawitaningtyas, Kumadji, \& Sunarti (2015) keputusan pembelian konsumen adalah membeli merek yang disukai dengan berbagai cara yang ada. Pengambilan keputusan sebagai proses penting dalam perilaku konsumen sangat penting untuk dipahami pemasar.

Selanjutnya Sumarwan dalam Fani Puspita Sari \& Tri Yuniati (2016) mendefinisikan keputusan pembelian adalah kegiatan dimana yang dilakukan oleh konsumen untuk membeli dan mengkonsumsi suatu produk atau jasa dalam rangka untuk memenuhi kebutuhan dan keinginannya.

\section{Proses Pengambilan Keputusan}

Ada lima tahap yang dilalui konsumen dalam proses pengambilan keputusan yaitu pengenalan kebutuhan, pencarian informasi, evaluasi alternatif, keputusan pembelian , dan perilaku pascapembelian. Gambar berikut melukiskan proses tersebut :

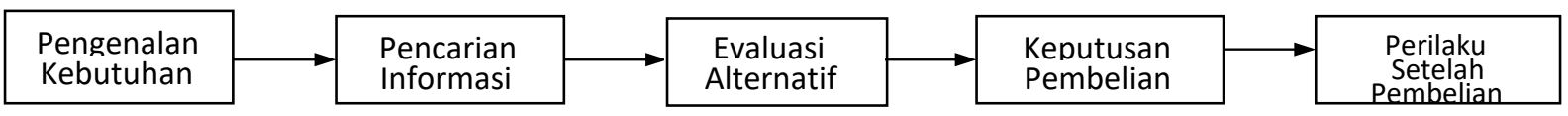

Gambar 1. Proses Pengambilan Keputusan Pembelian 


\section{METODE PENELITIAN}

Populasi dalam penelitian ini adalah konsumen Toko Mulia Internasional Fashion di Pekanbaru. Populasi dalam penelitian ini tersebar dan jumlahnya tidak diketahui secara pasti, maka pengambilan sampel dilakukan untuk penelitian ini. Sampel adalah bagian dari jumlah dan karakteristik yang dimiliki oleh populasi tersebut. Apabila peneliti melakukan penelitian terhadap populasi yang besar, sementara peneliti ingin meneliti tentang populasi tersebut dan peneliti memeliki keterbatasan dana, tenaga dan waktu, maka peneliti menggunakan teknik pengambilan sampel, sehingga generalisasi kepada populasi yang diteliti(Sugiyono, 2011). Adapun jumlah sampel dalam penelitian ini ditentukan dengan berdasarkan pada pendapat Roscoe dalam(Sugiyono, 2011) sehingga mendapatkan hasil berjumlah 100 responden.

Adapun teknik yang digunakan dalam usaha pengumpulan data untuk penelitian ini adalah sebagai berikut : (1) Wawancara, sebagai teknik komunikasi langsung untuk memperoleh data-data yang diperlukan serta ditujukan kepada semua pihak yang terkait dengan masalah yang diteliti. (2) Kuesioner, satu alat penelitian berupa daftar pernyataan untuk memperoleh informasi yang dibutuhkan dari responden terhadap layanan yang diberikan perusahaan dan pengaruh variabel terhadap kepuasan mahasiswa. (3) Observasi, digunakan untuk memperoleh gambaran atau fenomena yang terjadi pada responden yang berhubungan dengan masalah yang sedang diteliti.

Dalam penelitian ini, skala pengukuran yang digunakan adalah Skala Likert. Menurut Sugiyono (2010) Skala Likert digunakan untuk mengukur sikap, pendapat, dan persepsi seseorang atau sekelompok orang tentang fenomena sosial. Untuk menghindari jawaban bias karena responden cenderung memilih alternatif yang ada ditengah, maka digunakan 5 pilihan jawaban responden dalam kuesioner. Sehingga Instrumen pertanyaan atau pernyataan ini akan menghasilkan total skor bagi tiap anggota sampel yang diwakili oleh setiap nilai skor seperti instrumen dibawah ini : (1) SS = Sangat setuju diberi skor 5. (2) $S=$ Setuju diberi skor 4. (3) CS = Cukup Setuju diberi skor 3. (4) TS = Tidak setuju diberi skor 2. (5) STS $=$ Sangat tidak setuju diberi skor 1 .

Uji F menunjukkan apakah semua variabel independen atau bebas mempunyai pengaruh secaraserentak terhadap variabel dependen atau terikat (Ghozali, 2009).Derajat kepercayaan yang digunakan adalah $0,01,0,05,0,1$. Apabila nilai $\mathrm{F}$ hasil perhitungan lebih besar daripada nilai $\mathrm{F}$ menurut tabel maka hipotesis 
alternatif, yang menyatakan bahwa semua variabel independen secara simultan berpengaruh signifikan terhadap variabel dependen.

Model regresi merupakan model yang digunakan untuk menganalisis pengaruh dari berbagai variabel independen terhadap satu variabel dependen. Dalam penelitian ini terdapat beberapa variabel bebas yaitu life style $\left(\mathrm{X}_{1}\right)$, kualitas produk $\left(\mathrm{X}_{2}\right)$, dan store image $\left(\mathrm{X}_{3}\right)$ berpengaruh terhadap variabel terikat yaitu keputusan pembelian $(\mathrm{Y})$. Ada pun bentuk persamaan regresi linier berganda yang terstandardisir dan digunakan dalam penelitian ini, sebagai berikut (Ferdinand, 2011)

Keterangan :

$$
\mathrm{Y}=\mathrm{a}+\mathrm{b}_{1} \mathrm{X}_{1}+\mathrm{b}_{2} \mathrm{X}_{2}+\mathrm{b}_{3} \mathrm{X}_{3}+\mathrm{e}
$$

Y $\quad=$ Keputusan Pembelian

$\mathrm{a} \quad=$ Konstanta

$\mathrm{X} \quad=$ Life Style

$\mathrm{X}_{2} \quad=$ Kualitas Produk

$\mathrm{X}_{3} \quad=$ Store Image

$\mathrm{b}_{1}, \mathrm{~b}_{2}, \mathrm{~b}_{3}=$ Koefisien regresi variable independent

e $\quad=$ Error

\section{HASIL PENELITIAN}

\section{Uji Koefisien Determinasi $\left(\mathbf{R}^{2}\right)$}

Koefisien Determinasi $\left(\mathrm{R}^{2}\right)$ digunakan untuk melihat kemampuan variabel indenpenden dalam menerangkan variabel dependen, dimana jika nilia $\mathrm{R}$ square mendekati 1 (satu) maka variabel independen memberikan semua informasi yang dibutukan untuk memprediksi variasi variabel dependen.

Tabel 2

Hasil Uji Koefisien Determinasi $\left(\mathbf{R}^{2}\right)$

\begin{tabular}{ccccc} 
Model & $\mathrm{R}$ & R Square & Adjusted R Square & Std Error of the Estimate \\
\hline 1 & $0,680^{\mathrm{a}}$ & 0,463 & 0,446 & 0,42246 \\
\hline
\end{tabular}

Sumber: Data Olahan, 2018

Hasil menunjukan nilai Koefisien Determinasi (Adjusted $R$ Square) sebesar 0,446. Hal ini artinya bahwa variasi Keputusan Pembelian dijelaskan oleh Life Style, Kualitas Produk, dan StoreImage sebesar $44.6 \%$, sedangkan sisanya sebesar $55.4 \%$ dipengaruhi oleh variabel lainnya yang tidak diteliti dalam model. 


\section{Regresi Linear Berganda}

Hasil uji Regresi Linier Berganda dapat dilihat pada tabel sebagai berikut :

Tabel 3

Regresi Linear Berganda

\begin{tabular}{lccc}
\hline \multicolumn{1}{c}{ Model } & \multicolumn{2}{c}{$\begin{array}{c}\text { Unstandardized } \\
\text { Coeffcients }\end{array}$} & $\begin{array}{c}\text { Standardized } \\
\text { Coeffcients } \\
\text { Beta }\end{array}$ \\
\cline { 2 - 3 } & \multicolumn{1}{c}{ B } & Std.Error & \\
\hline (Counstant) & 0,273 & 0,487 & 0,590 \\
\hline Life_Style $(X 1)$ & 0,689 & 0,018 & 0,291 \\
\hline Kualitas Produk $(\mathrm{X} 2)$ & 0,282 & 0,073 & 0,029 \\
\hline Store Image $(\mathrm{X} 3)$ & 0,027 & 0,071 & \\
\hline
\end{tabular}

Sumber: Data Olahan, 2018

Persamaan regresi liniear berganda dalam penelitian ini adalah $: Y=0,273+$ $0,689 X_{1}+0,282 X_{2}+0,027 X_{3}+$ e. Persamaan regresi linier berganda di atas dapat dijelaskan sebagai berikut : (1) Dari regresi linier berganda tersebut diperoleh nilai konstanta $(\alpha)$ sebesar 0.273 yang artinya apabila Life Style, Kualitas Produk dan Store Image nilainya adalah 0, maka Keputusan Pembelian nilainya adalah 0.273 satuan. (2) Nilai koefisen regresi linier berganda variabel Life Style sebesar 0.689 yang berarti jika variabel independen lainya tetap dan Life Style mengalami kenaikan 1 satuan, maka Keputusan Pembelian akan mengalami kenaikan sebesar 0.689 satuan. Koefisen bernilai positif artinya terjadi hubungan positif, dimana Life Style yang tinggi akan meningkatkan Keputusan Pembelian. (3) Nilai koefisen regresi linier berganda variabel Kualitas Produk sebesar 0.282 yang berarti jika variabel independen lainya tetap dan Kualitas Produkmengalami kenaikan 1 satuan, maka Keputusan Pembelian akan mengalami kenaikan sebesar 0.282 satuan. Koefisen bernilai positif artinya terjadi hubungan positif, dimana Kualitas Produk yang tinggi akan meningkatkan Keputusan Pembelian. (4) Nilai koefisen regresi linier berganda variabelStore Imagesebesar 0.027yang berarti jika variabel independen lainya tetap dan Store Imagemengalami kenaikan 1 satuan, maka Keputusan Pembelian akan mengalami kenaikan sebesar 0.027 satuan. Koefisen bernilai positif artinya terjadi hubungan positif, dimana Store Image yang tinggi akan meningkatkan Keputusan Pembelian.

\section{Uji Parsial ( Uji t )}

Uji t digunakan untuk menguji signifikansi hubungan antara variable $\mathrm{X}$ dan variabel Y. Berikut adalah hasil perhitungan uji $t$ : 
Tabel 4

Hasil Uji Parsial (Uji t)

\begin{tabular}{llcccc}
\hline \multicolumn{1}{c}{ Variabel } & $\mathbf{T}_{\text {hitung }}$ & $\mathbf{T}_{\text {tabel }}$ & Sing & Keterangan \\
\hline $\mathbf{1}$ & Life Style & 7,810 & 2,627 & $0,000^{* * *}$ & $\begin{array}{c}\text { Berpengaruh signifikan dengan } \alpha \\
0,01\end{array}$ \\
\cline { 2 - 5 } & & & & $0,000^{* * * *}$ & $\begin{array}{c}\text { Berpengaruh signifikan dengan } \alpha \\
0,01\end{array}$ \\
\hline & 3,881 & 2,627 & & Tidak berpengaruh signifikan \\
\hline \multicolumn{2}{l}{ Kualitas Produk } \\
\end{tabular}

Sumber : Data Olahan, 2018

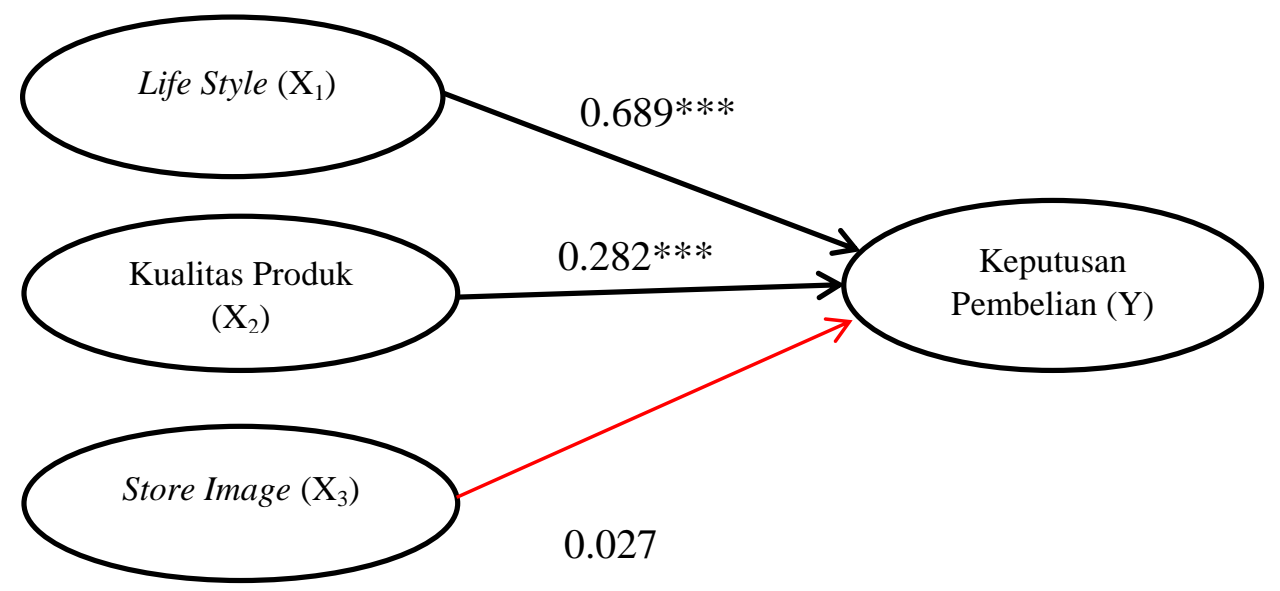

Gambar 3. Model Final Penelitian

Ket : $* * *=\operatorname{Sig} \alpha 0.01$

$\longrightarrow$ Supported Relation

Hasil pengujian secara parsial dapat dijelaskan sebagai berikut : (1) Hipotesis 1 artinya hasil pengujian menunjukkan bahwa nilai $\mathrm{T}$ hitung untuk variabel Life Style sebesar $7.810>$ dari $\mathrm{T}_{\text {tabel }}$ sebesar 2.627 atau nilai signifikan $0.000<$ dari alpha 0.01 , maka $\mathrm{H}_{1}$ diterima, dengan berarti bahwa variabel life style berpengaruh signifikan terhadap keputusan pembelian konsumen di Toko Mulia Internasional Fashion di Pekanbaru. (2) Hipotesis 2 artinya hasil pengujian menunjukkan bahwa nilai $\mathrm{T}$ hitung untuk variabel Kualitas Produk sebesar 3.881> dari $\mathrm{T}_{\text {tabel }}$ sebesar 2.627 atau nilai signifikan 0.000 <dari alpha 0.01, maka $\mathrm{H}_{2}$ diterima, dengan berarti bahwa variabel kualitas produk berpengaruh signifikan terhadap keputusan pembelian konsumen di Toko Mulia Internasional Fashion di Pekanbaru. (3) Hipotesis 3 artinya hasil pengujian menunjukkan bahwa nilai $\mathrm{T}_{\text {hitung }}$ untuk variabel Store Image sebesar $0.386<$ dari $\mathrm{T}_{\text {tabel }}$ sebesar 1.660, maka $\mathrm{H}_{3}$ ditolak, dengan berarti variabel Store Image tidak berpengaruh dan tidak signifikan terhadap keputusan pembelian konsumen di Toko Mulia Internasional Fashion di Pekanbaru. 


\section{PEMBAHASAN}

\section{Pengaruh Life Style terhadap Keputusan Pembelian}

Diketahui bahwa variabel life style memiliki pengaruh yang signifikan terhadap keputusan pembelian konsumen di Toko Mulia Internasional Fashion Pekanbaru. Dapat dilihat dari tanggapan responden yang baik mengenai produk pakaian di Toko Mulia sesuai digunakan untuk aktivitas. mengingat bahwa setiap orang memiliki gaya hidup yang berbeda-beda, kemudian gaya hidup ini yang akan mempengaruhi budaya konsumsi konsumen. Sebagaimana yang diungkapkan oleh Satya Gunawan Yahya (2012) gaya hidup akan mempengaruhi keinginan seseorang untuk berperilaku dan akhirnya menentukan pilihan - pilihan konsumsi.Dari hasil penelitian yang dilakukan oleh peneliti terdahulu yaitu Lestari (2017), bahwa gaya hidup memiliki pengaruh yang signifikan terhadap keputusan pembelian. Penelitian sebelumnya sejalan dengan penelitian yang dilakukan saat ini bahwa variabel life style berpengaruh terhadap keputusan pembelian konsumen di Toko Mulia Internaasional Fashion Pekanbaru.

\section{Pengaruh Kualitas Produk terhadap Keputusan Pembelian}

Diketahui bahwa variabel kualitas produk memiliki pengaruh yang signifikan terhadap keputusan pembelian konsumen di Toko Mulia Internasional Fashion Pekanbaru.Toko Mulia bersedia bertanggung jawab terhadap produk yang mereka jual dengan memberikan konsumen garansi pergantian produk apabila terjadi kecacatan. Mengingat bahwasanya dalam membeli suatu produk konsumen akan selalu mempertimbangkan kualitas produk, jika produk itu baik diharapkan terjadi pembelian ulang terhadap produk tersebut.Sebagaimana yang diungkapkan oleh Keller\&Kotler (2009) kualitas produk adalah produk atau jasa yang telah memenuhi atau melebihi ekspektasi pelanggan semakin baik kualitas produk diharapkan dapat menarik konsumen untuk percaya dan membeli produk tersebut.Dari hasil penelitian yang dilakukan oleh peneliti terdahulu yaitu Citra (2016), bahwa kualitas produk memiliki pengaruh yang signifikan terhadap keputusan pembelian. Penelitian sebelumnya sejalan dengan penelitian yang dilakukan saat ini bahwa variabel kualitas produk berpengaruh terhadap keputusan pembelian konsumen di Toko Mulia Internaasional Fashion Pekanbaru. 


\section{Pengaruh Store Image terhadap Keputusan Pembelian}

Diketahui bahwa variabel store image tidak memiliki pengaruh yang signifikan terhadap keputusan pembelian konsumen di Toko Mulia Internasional Fashion Pekanbaru. Namun responden memiliki tanggapan yang baik terhadap store image di Toko Muia Internasional Fashion Pekanbaru. Dimata ataupun benak konsumen Toko Mulia memiliki reputasi yang baik, namun tidak hal nya untuk lokasi, konsumen merasa Toko Mulia letaknya tidak strategis. Hasil penelitian ini menunjukkan bahwa menciptakan sebuah citra yang baik bagi konsumen berarti memuaskan konsumen, mengingat konsumen yang merasa puas diharapkan akan melakukan pembelian. Sebagaimana yang diungkapkan oleh Sopiah \& Syihabudhin (2008) bahwa citra toko adalah kepribadian sebuah toko yang menggambarkan apa yang dilihat dan dirasakan oleh konsumen terhadap toko tertentu.Dari hasil penelitian yang dilakukan oleh peneliti terdahulu yaitu Gunawan (2010) bahwa store image memiliki pengaruh yang signifikan terhadap keputusan pembelian, penelitian sebelumnya tidak sejalan atau terdapat perbedaan dengan penelitian yang dilakukan saat ini bahwa variabel store image tidak berpengaruh signifikan terhadap keputusan pembelian konsumen di Toko Mulia Internasional Fashion Pekanbaru.

\section{SIMPULAN}

Berdasarkan hasil penelitian, dapat ditarik kesimpulan : (1) Variabel Life Style $\left(\mathrm{X}_{1}\right)$ berpengaruh signifikan terhadap Keputusan Pembelian konsumen di Toko Mulia Internasional Fashion Pekanbaru. (2) Variabel Kualitas Produk $\left(\mathrm{X}_{2}\right)$ berpengaruh signifikan terhadap Keputusan Pembelian konsumen di Toko Mulia Internasional Fashion Pekanbaru. (3) Variabel Store Image $\left(\mathrm{X}_{3}\right)$ berpengaruh signifikan terhadap Keputusan Pembelian konsumen di Toko Mulia Internasional Fashion Pekanbaru. Berdasarkan hasil pembahasan dalam penelitian ini, maka saran dalam penelitian ini yaitu perlu dilakukan penelitian lebih lanjut terhadap faktor-faktor selain Life Style, Kualitas Produk dan Store Image yang berpengaruh terhadap Keputusan Pembelian Konsumen di Toko Mulia Internasional Fashion Pekanbaru. Hal ini dikarenakan dalam penelitian ini ketiga variabel tersebut hanya mampu menjelaskan $44.6 \%$ variasi keputusan pembelian sedangkan sisanya sebesar $55.4 \%$ dijelaskan oleh penelitian yang lain yang tidak diteliti dalam penelitian ini. 


\section{DAFTAR PUSTAKA}

Abdurrahman, H. N. (2015). Manajemen Strategi Pemasaran. In Pustaka Setia (Ed.) (Cetakan 1, p. 472).

Ali, H. (2011). Marketing dan Kasus-kasus Pilihan. In CAPS Yogyakarta (Ed.), CAPS (Center For Academic Publishing Service) (cetakan 2).

Assauri, S. (2009). Manajemen Pemasaran Konsep Dasar dan Strategi. In PT Raja Grafindo Persada Jakarta (Ed.) (Edisi Pert, p. 300).

Citra, R. Y. (2016). Analisis Pengaruh Citra Merek ,Harga dan Kualitas Produk Terhadap Keputusan Pembelian Produk Christian Andrie Chocolate di Pekanbaru. Stie Pelita Indonesia.

Ferdinand, A. (2011). Metode Penelitian Manajemen. In S. Indoprint (Ed.).

Ghozali, I. (2009). Aplikasi Analisis Multivariate Dengan Program IBM SPSS. Semarang: Badan Penerbit Universitas Diponegoro.

Ghozali, I. (2011). Aplikasi Analisis Multivariate dengan Program SPSS. In S. B. P. U. Diponegoro (Ed.).

Gunawan, P. (2010). Analisis Pengaruh Citra Toko Terhadap Keputusan Pembelian Konsumen pada Supermarket Mandiri Simpang Bahagia Medan.

Juliandi, A. (2013). Metodelogi Penelitian Kuantitatif Untuk Ilmu-Ilmu Bisnis. In Medan:M2000 (Ed.).

Keller\&Kotler. (2009). Manajemen Pemasaran. In Jakarta:Erlangga (Ed.) (Edisi 13 J).

Keller, K. (2016). Manajemen Pemasaran. In Jakarta Raja Grafindo (Ed.) (Edisi 1, c, pp. 120-323). https://doi.org/10.1016/j.electacta.2014.10.067

Kotler, P., \& Armstrong, G. (2014). Principle Of Marketing 15 Edition. In New Jersey: Pearson Prentice Hall (Ed.) (15th ed., p. 2014). https://doi.org/10.1016/j.neuroimage.2008.10.043.Automated

Lestari, A. (2017). Pengaruh Gaya Hidup dan Sikap Konsumen Terhadap Keputusan Pembelian Produk Secara Online di Kota Makassar Fakultas Ekonomi Bisnis dan Islam, Universitas Negeri Alauddin.

Lupiyoadi, R. (2014). Manajemen Pemasaran Jasa Berbasis Kompetensi. In Jakarta: Salemba Empat (Ed.) (Edisi 3).

Mardiansyah. (2016). Analisis Hubungan Citra Merek dan Perilaku Konsumen Terhadap Keputusan Pembelian Sepeda Motor pada PT Asia Surya Perkasa Cabang PangkalPinang. Jurnal Manajemen, 10.

Maretha, V., \& Kuncoro, E. A. (2011). Pengaruh Store Atmosphere dan Store Image pada Toko Buku Gramedia Pondok Indah Fakultas Ekonomi dan Bina Nusantara University, 2, 979-991..

Pawitaningtyas, M. R., Kumadji, S., \& Sunarti. (2015). Pengaruh Green Advertising Terhadap Citra Merek Serta Dampaknya Pada Keputusan Pembelian, 25(1), 1-7.

Philip Kotler \& Gery Amstrong. (2008). Marketing. In N. J. P. Hall (Ed.) (10th ed.).

Pratama, A. K. (2015). Analisis Pengaruh Gaya Hidup, Promosi, dan Kualitas Produk Terhadap Keputusan Pembelian Smartphone Samsung Wilayah Jakarta Pusat Fakultas Ekonomi dan Bisnis Universitas Islam Negeri Syarif Hidayatullah.

Sari, Fani Puspita \& Tri Yuniati. (2016). Pengaruh Harga, Citra Merek dan Word Of Mouth Terhadap Keputusan Pembelian Konsumen. Jurnal Imu Dan Riset Manajemen, 5.

Soebagyo, Tommy \& Dr Hartono M.M. (2014). Analisa Pengaruh Store Image Terhadap Purchase Intention di Toserba Ramai Ngawi. Jurnal Manajemen Pemasaran, 1(2). 
Solomon, Michael R. (2011). Customer Behavior. In N. J. P. A. Wesley (Ed.) (9th ed.) Sopiah \& Syihabudhin. (2008). Manajemen Bisnis Ritel. In Y. A. Offset (Ed.).

Sugiyono. (2010). Metode Penelitian Pendidikan Pendekatan Kuantitatif, kualitatif, dan $R \& D$. Bandung: Alfabeta.

Sugiyono. (2011). Metode Penelitian Kuantitatif,Kualitatif dan R\&D. In Bandung:Afabeda (Ed.).

Tjiptono, F. (2008). Strategi Pemasaran. In Yogyakarta: Andi (Ed.) (Edisi 3).

Yahya, Satya Gunawan. (2012). Pengaruh Word Of Mouth, Inovasi,Gaya Hidup dan Perceived Quality Terhadap Keputusan Pembelian.

Wijaya, Christian Hadi. (2013). Pengaruh Store Image, Store Admosphere dan Store Theatrics Terhadap Purchase Intention pada The Body Shop Galaxy Mall Surabaya 